\title{
THE IMPACT OF COVID-19 ON THE WORLD ECONOMY GLOBALIZATION
}

\author{
Dugienko N.O., Bondarenko A.G. \\ Zaporizhia National University \\ street Zhukovsky, 66, Zaporozhye, Ukraine \\ dugienkonata@ukr.net, anastazii007@gmail.com \\ ORCID: 0000-0002-4551-5548, ORCID: 0000-0003-4018-0539
}

Key words:

COVID-19 pandemic, GDP, globalization, world economy, business adaptation.
The article examines the COVID-19 impact pandemic on the world economy globalization. From the end of the 20th century and the beginning of the 21 st century, globalization began to cover all processes of human life. This is especially true of economic processes in the world. In the article reveals the problems faced by businesses in each country due to quarantine restrictions. The concept of global economy and the reasons of occurrence of such phenomenon are analyzed. The fall of GDP in the countries of the world, difficulties of the organization of conducting business activity in modern conditions and possibilities of occurrence of interdependence of automation and unemployment are investigated. The downward trend in GDP has shown its dependence on the restrictions adopted by countries in the first and second quarters of 2020. In the third quarter of 2020, improvements can be observed as quarantine restrictions are lifted. The article notes that large enterprises, due to their resource potential, have invented ways to adapt their activities to the constraints caused by the pandemic. Most employees of enterprises have been transferred to a flexible mode of operation, and sme: online mode in conjunction with work in offices. There was a rapid transition of business to the Internet. The problem of job loss due to the spread of automation in the activities of enterprises is highlighted. Some companies see the automation of business processes as prospects for their development, so they begin to actively invest in this area of innovation. Problems related to automation, namely: rising unemployment, will need to be addressed by business and government together. The tendencies to deepen global processes and accelerate the application of new technologies are considered. It is noted that the deepening globalization of the economy will be due to large mergers, as they have more capacity and ability to stay in the market in today's realities. Examples are given of how enterprises adapted and were able to maintain their positions during the pandemic. Despite all the problems facing large firms in 2020 due to the pandemic, globalization will intensify. After all, large enterprises have the resources to adapt quickly to crises.

\section{ВПЛИВ COVID-19 НА ГЛОБАЛІЗАЦІЮ СВІТОВОЇ ЕКОНОМІКИ}

\section{Ключові слова:}

пандемія COVID-19, ВBП, глобалізація, світова економіка, адаптація бізнесу.

\section{Дугієнко Н.О., Бондаренко А.Г.}

Запорізький національний університет

вул. Жуковського, 66, м. Запоріжжся, Украӥна

У статті досліджується вплив пандемії COVID-19 на глобалізацію світової економіки. 3 кінця 20 століття та початку 21 століття глобалізація почала охоплювати всі процеси людського життя. Особливо це стосується економічних процесів у світі. Стаття розкриває проблеми, які постали перед бізнесом в кожній країні, через карантинні обмеження. Аналізується поняття глобальної економіки й причини появи такого явища. Досліджується падіння ВВП в країнах світу, труднощі організації ведення бізнесової діяльності в сучасних умова та можливості виникнення взаємозалежності автоматизації та безробіття. Тенденція до зниження ВВП продемонструвала свою залежність від обмежень, прийнятих країнами у першому та другому кварталах 2020 року. У третьому кварталі 2020 року можна спостерігати поліпшення, коли скасовуються карантинні обмеження. У статті зазначається, що великі підприємства завдяки своєму ресурсному потенціалу винайшли способи адаптувати свою діяльність до обмежень, спричинених пандемією. Більшість співробітників підприємств переведено на гнучкий режим роботи, 
а також режим «онлайн» разом із роботою в офісах. Відбувся швидкий перехід бізнесу в Інтернет. Висвітлено проблему втрати робочих місць через поширення автоматизації у діяльності підприємств. Розглядаються тенденції до поглиблення глобальних процесів та прискорення застосування новітніх технологій. Зазначається, що поглиблення глобалізації економіки відбуватиметься за рахунок великих об'єднань підприємств, оскільки вони мають більше потужностей та можливостей втриматися на ринку в сучасних реаліях. Надаються приклади як підприємства адаптувались та змогли втримати свої позиції під час пандемії.

\section{Statement of the problem}

The outbreak of COVID-19 pandemic in 2020 has significantly affected the globalization process in the world. The world economy was not left out either. As businesses face new challenges and the need to adapt their activities to modern conditions, the globalization of the world economy has a tendency to deepen.

\section{Analysis of recent studies and publications}

In the current economic situation, it is still difficult to exactly assess the impact of the pandemic on the world economy, as more important conclusions and reports of various organizations on the study of the modern economic space can be seen as early as in 2021. But despite this, scientists are still trying to study the state of the world's economies under the impact of COVID-19. For example, researchers D.V. Dolbnieva and M. Stadnyk have analyzed the state of the world's economies during the pandemic [1], [2]. Also, S. Kulytskyi studied the prospects for the development of Ukraine's economy during the pandemic [3]. Research centers such as: PRICEWATERHOUSECOOPERS GROUP [4], the World Trade Organization [5] and others pay special attention to the impact of the pandemic on various economic aspects.

\section{Objectives of the article}

The purpose of this Article is to analyze the impact of the COVID-19 pandemic on the globalization of the world economy and ways to adapt business to modern conditions.

\section{The main material of the research}

At the end of the 20th century, a new type of economy emerged - the global economy. Its distinctive feature is that all major economic activities are carried out on a global scale. Global corporations have emerged, representing large financial and industrial, scientific and technological, and trade and service associations. The main reason of globalization is to maximize profits as the main motive for foreign investment [6].

Kofi Annan, former UN Secretary-General, said at the jubilee session of the UN that globalization is already integrated into virtually all interactions of societies, enterprises, markets and economies around the world.

With the collapse of the world economy into socialist and capitalist, most countries have moved to market relations in their economies. This was the impetus for the beginning of globalization. It is the liberalization of relations between countries, the exchange of labor resources, migration that have created the prerequisites for opportunities to introduce changes at the legislative, administrative and social levels. This is exactly what led to the globalization of economic relations in the world.
In the late 20th and early 21 st century, the world faced many global issues: environmental, energy, demographic, food, debt. The shadow economy is also a global problem for many countries.

All these processes, their interpenetration in the countries of the world, the issue of solving global problems create the prerequisites for the emergence of economy globalization. By the beginning of the 21 st century, all these trends have led the world to create a full-fledged global economy. As globalization occurs in many areas of people's lives, it can be called a universal tool for building a new world economy.

Aspects of human life affected by globalization interact, penetrating each other, thus connecting the economy with politics, social processes with the environment, etc. [7].

The COVID-19 pandemic, which broke out in early 2020, has given impetus to the further development of globalization in the world. Due to the pandemic, global processes have deepened, as societies and businesses have faced the question "What to do?" and "How to continue doing business?".

Let's analyze the impact of the pandemic on the world's GDP. In the second quarter of 2020, many economies around the world fell sharply (Figure 1).

You can also observe the fall in GDP of the EU countries (Fig. 2, 3).

We can see from Figure 2 that the total GDP of the EU countries improved in Q3 of 2020. This trend was due to the fact that countries have lifted certain restrictions that were introduced in early 2020 due to the pandemic.

But Figure 3 shows the trend of real GDP decline due to the health care crisis.

It is noted that the COVID-19 pandemic could be a turning point in the era of globalization, as many companies around the world need to comply with the rules and decisions taken by the authorities regarding the pandemic.

In early 2020, the world economy was already in crisis. With the spread of the COVID-19 disease, businesses started facing problems related to obtaining the necessary resources from suppliers in other countries. Due to this, there was a need to adapt the activities of enterprises to the current situation.

Different companies have found their own ways to change. For example, the restaurant business has switched to takeaway and online order services through websites and mobile applications. Firms that sell consumer goods and services have also turned their activities to the Internet, at times reducing their own production capacity, in order to support the production of personal protective means and other products that are in high demand today. 


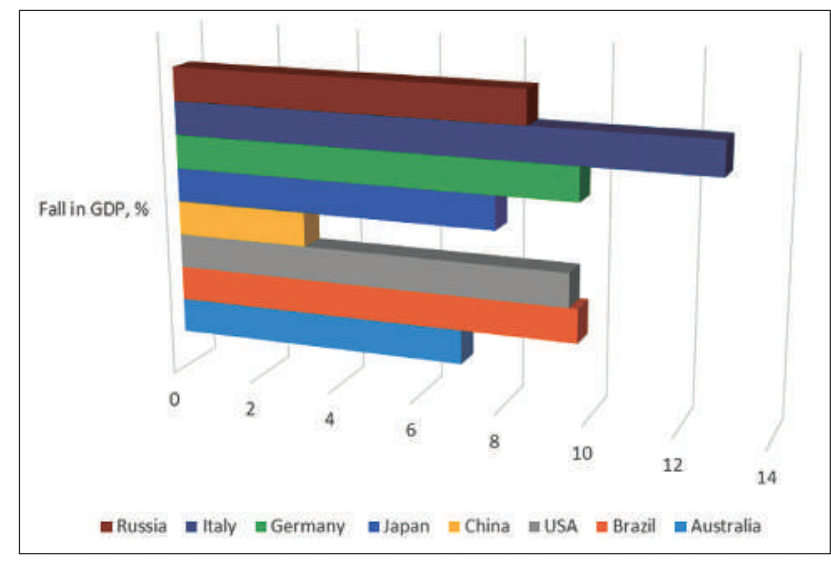

Fig. 1. Fall in GDP by countries with the highest number of patients with COVID-19, Q2 2020

Source: created by the authors based on the data [8].

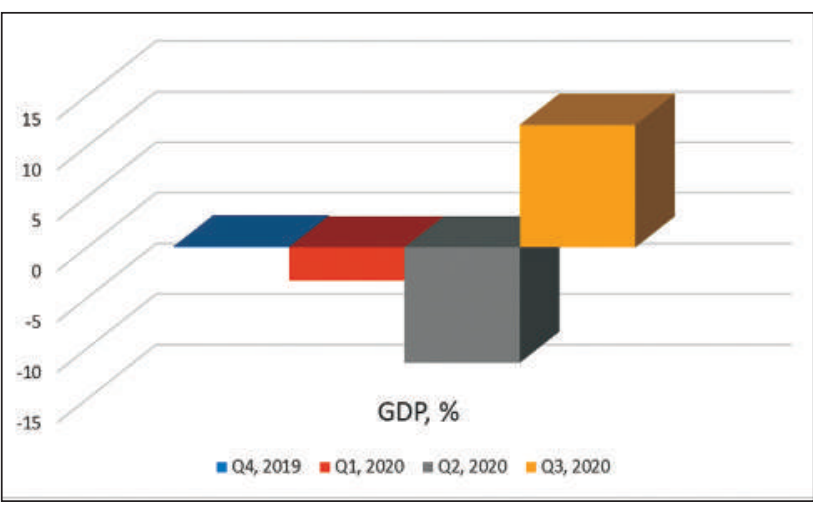

Fig. 2. Aggregate GDP fluctuation rates in the EU countries compared to previous quarters, Q4 2019 - Q3 2020

Source: created by the authors based on the data [9].

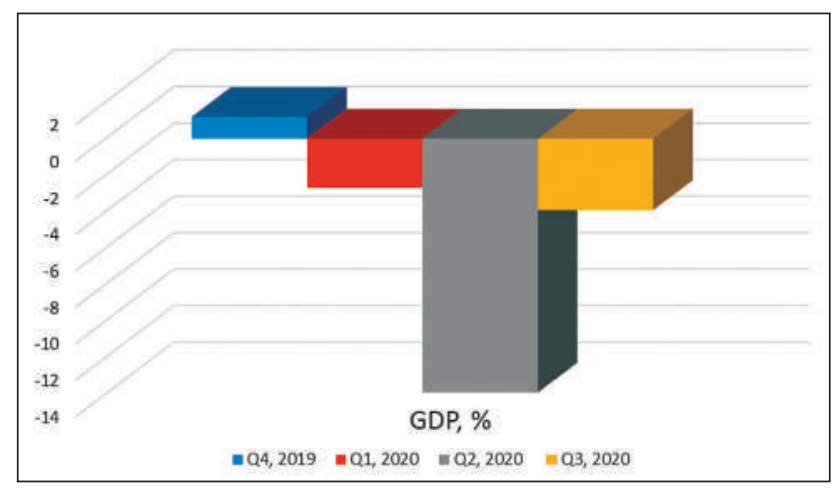

Fig. 3. Aggregate GDP fluctuation rates in the EU countries compared to previous quarters, Q4 2019-Q3 2020

Source: created by the authors based on the data [9].

Modern conditions have pushed business to shift negotiations, meetings, presentations, seminars, demonstrations of new products in the virtual area. All of this has made companies dependent on the quality of the
Internet and software, but has helped keep employees healthy and safe.

The above changes will have negative consequences for many areas of the economy, where there are opportunities to automate processes that will reduce the number of jobs. This will increase unemployment. Therefore, states and enterprises will need to develop programs for training and adaptation of employees to new realities of work.

Also, large companies such as Fujitsu are expanding investments in automation to improve their own productivity and competitive market position [10], [11].

Developed countries, where society trusts the government, citizens listen to the demands and measures taken by the authorities to prevent the spread of the virus, will be able to overcome the above problems faster. However, alongside this another problem emerges, such as attempts to use personal data. For instance, in some countries, data from mobile phones and other devices have been used to monitor the population in order to prevent the spread of COVID-19. Digital monitoring and the use of personal data as a control system aimed to achieve the highest goal - to preserve the population health. But the main priority of the European regulation on personal data protection remains to restrict access to personal data from outsiders, including the state.

Francis Fukuyama, the American philosopher, political economist, noted that the crisis caused by the COVID-19 pandemic will ensure the effectiveness of those governments that will fight the effects of the pandemic [12].

Although the global economy faces the challenges of closing borders and restricting foreign deliveries, globalization will in the future tend to accelerate and deepen due to the constant use of new technologies and the Internet.

Let's look at the impact of the pandemic on the globalization of economic processes using the example of a large association of enterprises in Ukraine - DTEK, the financial and industrial group of companies. The situation that developed in the world in 2020 due to the COVID-19 pandemic has made its impact on the activities of the group as a whole.

Like most large companies in the world, DTEK Group's companies faced the negative consequences of the pandemic:

1. Restrictions due to quarantine and lock-down have led to problems of communication with foreign partners and the ability to manage companies.

2. The inability to travel abroad has caused problems with regard to contract conclusion, and in some cases problems with opening and maintaining accounts in foreign banks, as the direct presence of authorized staff is required.

3. During the severe quarantine and lock-down, many employees were not able to get to work, therefore the managers of enterprises were forced to suspend production activities, i.e. to have the staff in downtime while paying them wages.

The above restrictions had a negative impact on DTEK Group's operations, but thanks to it being the large group, it was easier for companies to adapt to the new business environment, while smallest businesses did not have the chance to do so. 
In modern conditions, companies have introduced certain changes in their activities:

1. A combination work schedule has been put in place for the employees, whenever possible. In other words, employees work according to a schedule that indicates when they work in the office and when from home (hybrid mode).

2. During quarantine, those employees who do not need to be in the office, were transferred to remote work (use of online conferences, through various programs, providing employees with the necessary equipment, etc.).

3 . In places where the round-the-clock presence of employees is required, a shift regime was adopted, i.e. the employees were provided with all required living amenities for a period of two weeks. Employees rotate every two weeks.

As DTEK Group companies were able to continue and adapt their operations to modern conditions, the management had the opportunity to provide the following assistance to their employees:

1. Transportation of employees to workplaces.

2. Provision of personal protective equipment to employees to avoid the spread of the disease.

3 . Entry into agreements with medical institutions to conduct testing for the corona virus at the expense of enterprises.

After six months of remote operation, namely hybrid operation mode, a survey was conducted among employees with regard to the comfort of such operation mode.
$71 \%$ of employees said that they were satisfied with such operation mode, because they stay in touch with the manager by working in the office one or two days a week. At the same time, employees feel safe working more in online mode [13].

\section{Conclusions}

Thus, the emergence of a pandemic has accelerated the global economic crisis and caused a fall in GDP in each country. A more significant deterioration of GDP rating was observed in the first and second quarters of 2020, due to quarantine and strict territorial restrictions in the countries. Some improvement was observed in the third quarter of 2020, following the reduction of quarantine restrictions. This gives hope for the recovery of the world's economies after the recession of the pandemic.

The current situation has affected all business processes and people's lives, including the processes of globalization. Large companies and their associations can withstand change and continue to operate, implementing adaptive and innovative measures of business activities. The processes caused by the pandemic have prompted companies to accelerate decisions on implementing changes in their activities with the application of the latest technologies. The pandemic has also taught businesses how to respond quickly to changing working conditions in order to avoid future losses and stay in the market.

\section{References}

1. Dolbnyeva D.V. Vplyv COVID-19 na ekonomiku krayin svitu [The Impact of COVID-19 on the World's Economies]. Retrieved from: https:/www.problecon.com/export_pdf/problems-of-economy-2020-1_0-pages-20_26.pdf [in Ukrainian].

2. Stadnyk M. Vplyv COVID-19 na svitovu ekonomiku. Retrieved from: https://msfz.ligazakon.ua/ua/magazine article/FZ002118 [in Ukrainian].

3. Kulyts'kyy S. Problemy rozvytku ekonomiky Ukrayiny, obumovleni pandemiyeyu koronavirusu COVID-19 u sviti, ta poshuk shlyakhiv yikh rozv'yazannya. Retrieved from: http://www.nbuviap.gov.ua/index.php?option=com con tent\&view=article\&id=4889: otsinka-perspektiv-rozvitku-ukrajinskoji-ekonomiki-v-umovakh-pandemiji-covid19\&catid=8\&Itemid=350 [in Ukrainian].

4. COVID-19: Impacts to business. Retrieved from: https://www.pwc.com/gx/en/issues/crisis-solutions/covid-19.html [in English].

5. COVID-19 and world trade. Retrieved from: https://www.wto.org/english/tratop_e/covid19_e/covid19_e.htm [in English].

6. Vliyaniye globalizatsii $\mathrm{v}$ turizme [The impact of globalization in tourism]. Retrieved from: http://uctopuk.info/ article/vliyanie-globalizacii-v-turizme [in Russian].

7. Hlobalizatsiya ekonomiky, zmist ta osnovni formy proyavu [Globalization of the economy, content and main forms of manifestation]. Retrieved from:https://studme.com.ua/195106186880/ekonomika/globalizatsiya_ekonomiki_ soderzhanie_osnovnye_formy_proyavleniya.htm [in Ukrainian].

8. Pandemiya COVID-19 sprychynyla rekordne padinnya svitovoyi ekonomiky [The COVID-19 pandemic caused a record downturn in the world economy]. Retrieved from: https://www.ukrinform.ua/rubric-economy/3091815pandemia-covid19-spricinila-rekordne-padinna-svitovoi-ekonomiki-zmi.html [in Ukrainian].

9. Ofitsiynyy sayt Yevrostatu [Official website of Eurostat]. Retrieved from: https://ec.europa.eu/eurostat [in Ukrainian].

10. The COVID Impact on Business Globalization: What Does the Future Hold? Retrieved from: https://www. europeanbusinessreview.com/the-covid-impact-on-business-globalization-what-does-the-future-hold/ [in English].

11. COVID-19 has changed the business landscape: how will manufacturers adapt? Retrieved from: https://blog.global.fujitsu.com/fgb/2020-08-16/covid-19-has-changed-the-business-landscape-how-willmanufacturers-adapt-2/ [in English].

12. Hlobal'na kryza vid COVID-19 nasuvayet'sya. Shcho bude pislya? [The global crisis of COVID-19 is approaching. What will happen next?]. Retrieved from: https://minjust.gov.ua/ [in Ukrainian].

13. Ofitsiynyy sayt DTEK [DTEK's official website]. Retrieved from: https://minjust.gov.ua/ [in Ukrainian]. 